Article

\title{
Physico-Chemical Changes, Microbiological Properties, and Storage Shelf Life of Cow and Goat Milk from Industrial High-Pressure Processing
}

\author{
Sok Fern Tan ${ }^{1}$, Nyuk Ling Chin ${ }^{1, * \mathbb{D}}$, Tuan Poy Tee ${ }^{2}$ and Sook Kuan Chooi ${ }^{3}$ \\ 1 Department of Process and Food Engineering, Faculty of Engineering, Universiti Putra Malaysia, \\ UPM Serdang 43400, Selangor, Malaysia; ferncharlotte@hotmail.com \\ 2 Department of Animal Science, Faculty of Agriculture, Universiti Putra Malaysia, \\ UPM Serdang 43400, Selangor, Malaysia; ttpoy@upm.edu.my \\ 3 Kara F\&B Productions Sdn Bhd, 5, Jalan Signature Industrial Park 2, Signature Industrial Park, \\ Semenyih 43500, Selangor, Malaysia; sharonchui@jussu.com.my \\ * Correspondence: chinnl@upm.edu.my; Tel.: +6-03-97696353
}

Received: 21 March 2020; Accepted: 11 April 2020; Published: 16 June 2020

\begin{abstract}
Industrial high-pressure processing (HPP) was conducted on cow and goat milk in comparison to conventional heat pasteurization. No significant changes were found in the physico-chemical properties of the treated milk except for $\mathrm{pH}$, where pasteurized cow milk experienced a decrease while goat milk's pH increased for both pasteurized and HPP treated. HPP-treated cow and goat milk both achieved microbial shelf life of 22 days at $8^{\circ} \mathrm{C}$ storage with no increase in Bacillus cereus, mesophilic aerobic spores, coliform, yeast and mold but slight increase in psychrotrophic bacteria and total plate count. Pasteurized goat milk was spoilt at the end of storage with exceeding count of psychrotrophic bacteria $\left(9.0 \times 10^{8} \mathrm{CFU} / \mathrm{mL}\right)$ and total plate count $\left(3.5 \times 10^{8} \mathrm{CFU} / \mathrm{mL}\right)$. HPP-treated cow milk exhibited higher physico-chemical stability than goat milk as evidenced by non-significant change of titratable acidity but goat milk experienced an increase of $0.04 \%$ averagely.
\end{abstract}

Keywords: milk quality; high pressure processing; pasteurization; milk storage; shelf life

\section{Introduction}

Milk is well-known as a major source of dietary energy, protein, and fat. It contributes 134 kcal of energy/capita per day on average [1]. Apart from cow milk, goat milk has also started to gain interest worldwide in recent years [2]. Goat milk contains lower amount of caseins by $89 \%$ compared to cow milk, hence gives a greater digestive utilization compared to cow milk [3]. However, the nature of milk and its chemical composition render it as one of the ideal culture media for microbial growth and multiplication [4]. Hence, the major challenge in milk industries is to ensure delivery of safe and healthy milk products of consistent quality to an ever-increasing demand of milk.

Thermal treatments such as pasteurization high temperature short time (HTST-72 $\left.{ }^{\circ} \mathrm{C} / 15 \mathrm{~s}\right)$, low temperature long time (LTLT-63 ${ }^{\circ} \mathrm{C} / 30 \mathrm{~min}$ ), and ultra-high temperature (UHT-135 ${ }^{\circ} \mathrm{C} / 3 \mathrm{~s}$ ) are usually used to treat raw milk in order to be rendered safe for consumer and increase its shelf life [5]. Studies have shown that microbial population counted is significant beyond 20 days of storage for pasteurized milk [6-8]. UHT-treated milk typically has up to 4-6 months of commercial shelf life at ambient temperature [9]. However, these conventional heat treatments have detrimental effects on the nutrient content of milk. Studies have proven that thermal treatments caused 5-15\% of whey protein denaturation, $10-25 \%$ of water soluble vitamins destruction, disturbed structure of casein micelles, and also enhancement of allergenic properties of milk proteins $[5,10,11]$. 
High pressure processing (HPP) is a promising alternative to conventional thermal treatments as it is capable to inactivate foodborne pathogens while minimizing the loss of nutrients, such as water-soluble vitamins and maintaining the fresh-like characteristics of food products [12-14]. During HPP, pressure is allowed to remain in contact with the product for a specific holding time to activate the destruction of spore and microbes, and formation of non-covalent bonds of food components to gelatinize the enzyme $[13,15,16]$. Pressure regime of 200-600 MPa with holding time of 3-10 min is usually applied in HPP of milk. Generally, higher pressure resulted in higher rate of microbial destruction as well as longer shelf life. Pereda et al. [17] reported a shelf life of 14-18 days for milk treated at $200 \mathrm{MPa}$ at storage temperature of $4{ }^{\circ} \mathrm{C}$. Mussa and Ramaswamy [18] reported that pressure of $350 \mathrm{MPa}$ renders a milk shelf life of 18 days at similar storage temperature. When milk was treated at $600 \mathrm{MPa}$, shelf life of 28 days was achieved at similar storage temperature [14]. Storage temperature of milk also plays a role in milk's shelf life. Rademacher and Kessler [19] reported that milk subjected to pressure treatment of $400 \mathrm{MPa}$ for $15 \mathrm{~min}$ or $600 \mathrm{MPa}$ for $3 \mathrm{~min}$ could only achieve 10 days of shelf life when stored at $10^{\circ} \mathrm{C}$, which is 18 days shorter than that of storing at $4{ }^{\circ} \mathrm{C}$.

While studies about the HPP effects on nutrient content like fat, protein, and moisture are very limited, several studies have proven that HPP is able to preserve vitamins in milk better than pasteurization and UHT $[20,21]$. From the microbiological perspective, a more pronounced microbial inactivation was obtained by increasing HPP pressure levels and holding time. Alexandros et al. [14] reported that HPP above $550 \mathrm{MPa}$ and 3 min reduced the number of E. coli, Salmonella spp., and L. monocytogenes to below limit of detection while pressure regime of $400 \mathrm{MPa}$ for 1 min did not result in statistically significant differences in reduction levels. Yang et al. [22] reported that holding time of $30 \mathrm{~min}$ at $300 \mathrm{MPa}$ is sufficient to inactivate Salmonella spp., E. coli, Shigella, and S. aureus.

Most HPP studies conducted on milk are based in countries with seasonal climates. For a hot tropical country like Malaysia, HPP for milk is a new technology. Because of the high consumption of pasteurized UHT milk, this study was conducted to investigate industrial HPP effects on local cow and goat milks in terms of its physico-chemical and microbiological properties. The changes in milk properties were measured at storage temperature of $8^{\circ} \mathrm{C}$ following commercial handing practices for 22 days and compared with pasteurized milk.

\section{Materials and Methods}

\subsection{Milk Sampling and Treatment}

Total of 10 liters of fresh cow milk was collected from the university farm, Ladang 16, Universiti Putra Malaysia while fresh goat milk was collected from a private farm, Janggut Ternak Farm, Dengkil, Selangor, Malaysia. The milk was maintained below $10^{\circ} \mathrm{C}$ during transportation to the HPP facility (Kara F\&B Productions, Sdn. Bhd.) within $1 \mathrm{~h}$ for bottling into HPP grade plastic bottles of $250 \mathrm{~mL}$ after a thorough stirring. Three bottles of milk sample, each for cow and goat was used directly for analysis as control or fresh milk samples.

The two HPP pressures applied were $450 \mathrm{MPa}$ and $600 \mathrm{MPa}$ for two durations, $5 \mathrm{~min}$ or $7 \mathrm{~min}$ at $15 \pm 2{ }^{\circ} \mathrm{C}$. The three HPP treatments combinations were $450 \mathrm{MPa} / 7 \mathrm{~min}, 600 \mathrm{MPa} / 5 \mathrm{~min}$, and $600 \mathrm{MPa} / 7 \mathrm{~min}$ giving a total of 27 milk samples, i.e., $3 \mathrm{HPP}$ treatments $\times 3$ storage durations of 0,11 , and 22-days $\times 3$ analysis which include the physico-chemical and microbiological properties. Both cow and goat milk samples were loaded into the pressure chamber of HPP unit with $55 \mathrm{~L}$ volume (Hiperbaric 55, Hiperbaric, Spain) at the same time for the same treatment.

Pasteurization of cow and goat milk were done at $72{ }^{\circ} \mathrm{C}$ for at least $15 \mathrm{sec}\left(\mathrm{HTST}-72{ }^{\circ} \mathrm{C} / 15 \mathrm{~s}\right.$ ). Milk was poured into beakers which were pre-heated with boiling water to ensure sterile condition and heated in the water bath (BS-21, Jeio Tech, South Korea) with temperature monitored using clean thermocouples with regular stirring. After pasteurization, the milk was cooled rapidly to room temperature in an ice cooler box filled with ice cubes. Then, the milk was bottled into 9 plastic bottles 
(3 storage days $\times 3$ analysis) each for cow and goat milk. All treated milk samples were kept in a chiller (RV710, Hitachi, Japan) at $8 \pm 2{ }^{\circ} \mathrm{C}$ for storage until analysis.

\subsection{Physico-Chemical Analysis}

The $\mathrm{pH}$ values of both cow and goat milk samples were determined using a portable $\mathrm{pH}$ meter (Mi805, Milwaukee, Hungary). The $\mathrm{pH}$ meter was calibrated to the $\mathrm{pH}$ of the buffer solution at $25^{\circ} \mathrm{C}$. Titratable acidity was determined following AOAC Official Method 947.05. The specific gravity was determined following the method of AOAC 925.22 using a pycnometer. Total protein was determined using Pyne's method which is known as formaldehyde titration [23]. This method was proven to be having the same accuracy as compared to Kjeldahl method, as the differences were insignificant between protein contents measured by using both methods [24]. The total protein was calculated using factor of 1.74. The total solid of both cow and goat milk was determined using the oven drying method (UM500, Memmert, Germany) in accordance to AOAC Official Method 16.032 where total solid in percentage was calculated as follow:

$$
\text { Total solid }(\%)=\frac{\text { Weight of dish }+ \text { dried sample }- \text { Weight of empty dish }}{\text { Weight of sample }} \times 100
$$

The total fat percentage was determined following the AOAC Official Method 905.02, which is also known as the Roese-Gottlieb method. The total fat was calculated as follows:

$$
\text { Total Fat }(\%)=\frac{\text { Weight of flask containing fat }- \text { weight of flask after fat washing }}{\text { Weight of sample }} \times 100
$$

The milk solid-non-fat (SNF) was determined by subtracting the total solid (\%) with the total fat content $(\%)$.

\subsection{Microbiological Analysis}

Microbiological analysis was conducted in an aseptic environment to prevent cross contamination. The total plate count (TPC) and total yeast and mold count in milk were determined following methods in FDA Bacteriological Analytical Manual (BAM) Chapter 3 and 18, respectively. The total coliform count was determined following AOAC Official Method 991.14. The mesophilic, thermophilic aerobic spore count and psychrotrophic bacteria count were determined following Compendium of Methods for the Microbiological Examination of Foods (CMMEF) Chapter 23, 26, and 13, respectively. Bacillus cereus, Staphylococcus aureus, and Listeria monocytogenes were determined following FDA BAM Chapter 14,12, and 10, respectively. Escherichia coli and Clostridium perfringens were determined by AOAC Official Method 991.14 and 976.30, respectively. Salmonella spp. was determined using enzyme-linked immunosorbent assay (ELISA) method.

\subsection{Experimental Design and Statistical Analysis}

All measurements were done in duplicates with samples prepared from the same batch of milk. Minitab software (Version 16, Minitab Statistical Software, United States) was used to perform analysis of variance (ANOVA). Tukey's test was performed to compare the differences among the mean values at a confidence level of 0.05 .

\section{Results and Discussion}

\subsection{Effects of HPP on Physico-Chemical Properties}

Physico-chemical properties of cow and goat milk before and after the treatment are presented in Table 1. The $\mathrm{pH}$ of pasteurized cow milk decreased significantly $(p<0.05)$ from $6.59 \pm 0.01$ to $6.52 \pm 0.00$. In contrast, the $\mathrm{pH}$ of pasteurized goat milk increased significantly $(p<0.05)$ from $6.34 \pm 0.00$ to 
$6.38 \pm 0.01$. Ma and Barbano [25] reported that $\mathrm{pH}$ of cow skim milk decreases linearly with increasing temperature during treatment. However, José et al. [26] reported that pasteurization increased $\mathrm{pH}$ of bovine milk because of the lower whey protein associated with the casein micelles. Tamime [10] explained that the increase of $\mathrm{pH}$ is due to the reduced casein micelles where heat denatured its whey protein. For HPP-treated milk, pH for cow milk only changed slightly but statistically insignificant $(p>0.05)$. Nonetheless, $\mathrm{pH}$ of goat milk has increased significantly $(p<0.05)$. This increment is mainly due to the alteration of the distribution of minerals by HPP, which includes calcium, phosphate, and other ionized minerals such as calcium [27]. Other studies which have observed increase in the milk pH after HPP include Liepa et al. [28] who found that pressure of 500-600 MPa for 15 min increased the $\mathrm{pH}$ of cow milk; while Zobrist et al. [29] reported that pressure of 100-600 MPa for $30 \mathrm{~min}$ also caused an average 0.08 units of $\mathrm{pH}$ increment in cow milk.

Table 1. Physico-chemical properties of cow and goat milk before and after treatment.

\begin{tabular}{|c|c|c|c|c|c|}
\hline Analysis & Before Treatment & $450 \mathrm{MPa} / 7 \mathrm{~min}$ & $600 \mathrm{MPa} / 5 \mathrm{~min}$ & $600 \mathrm{MPa} / 7 \mathrm{~min}$ & Pasteurized \\
\hline \multicolumn{6}{|c|}{ Cow Milk } \\
\hline $\mathrm{pH}$ & $6.59 \pm 0.01^{\mathrm{a}}$ & $6.56 \pm 0.01^{a}$ & $6.58 \pm 0.00^{a}$ & $6.61 \pm 0.02^{a}$ & $6.52 \pm 0.00^{b}$ \\
\hline Titratable acidity & $0.16 \pm 0.01^{a}$ & $0.15 \pm 0.00^{a}$ & $0.16 \pm 0.01^{a}$ & $0.17 \pm 0.01^{\mathrm{a}}$ & $0.16 \pm 0.01^{\mathrm{a}}$ \\
\hline Specific gravity & $1.03 \pm 0.00^{\mathrm{a}}$ & $1.03 \pm 0.00^{\mathrm{a}}$ & $1.02 \pm 0.00^{\mathrm{a}}$ & $1.03 \pm 0.00^{\mathrm{a}}$ & $1.03 \pm 0.00^{a}$ \\
\hline Total protein & $3.13 \pm 0.00^{\mathrm{a}}$ & $2.87 \pm 0.12^{\mathrm{a}}$ & $3.04 \pm 0.12^{\mathrm{a}}$ & $3.04 \pm 0.12^{\mathrm{a}}$ & $2.96 \pm 0.25^{\mathrm{a}}$ \\
\hline Total fat & $3.33 \pm 0.08^{a}$ & $3.29 \pm 0.06^{\mathrm{a}}$ & $3.24 \pm 0.09^{a}$ & $3.30 \pm 0.14^{\mathrm{a}}$ & $3.32 \pm 0.08^{a}$ \\
\hline Total solid & $11.65 \pm 0.01^{\mathrm{a}}$ & $11.61 \pm 0.21^{a}$ & $11.55 \pm 0.19^{a}$ & $11.64 \pm 0.11^{\mathrm{a}}$ & $11.88 \pm 0.06^{\mathrm{a}}$ \\
\hline Solid-non-fat & $8.32 \pm 0.09^{a}$ & $8.32 \pm 0.15^{\mathrm{a}}$ & $8.31 \pm 0.28^{a}$ & $8.34 \pm 0.03^{a}$ & $8.56 \pm 0.14^{a}$ \\
\hline \multicolumn{6}{|c|}{ Goat Milk } \\
\hline $\mathrm{pH}$ & $6.34 \pm 0.00^{c}$ & $6.38 \pm 0.00^{b}$ & $6.42 \pm 0.01^{\mathrm{a}}$ & $6.38 \pm 0.01^{b}$ & $6.38 \pm 0.01^{b}$ \\
\hline Titratable acidity & $0.22 \pm 0.01^{\mathrm{a}}$ & $0.22 \pm 0.01^{a}$ & $0.22 \pm 0.01^{a}$ & $0.21 \pm 0.01^{a}$ & $0.23 \pm 0.01^{a}$ \\
\hline Specific gravity & $1.03 \pm 0.00^{\mathrm{a}}$ & $1.03 \pm 0.00^{\mathrm{a}}$ & $1.03 \pm 0.00^{\mathrm{a}}$ & $1.03 \pm 0.00^{\mathrm{a}}$ & $1.03 \pm 0.00^{a}$ \\
\hline Total protein & $3.57 \pm 0.12^{\mathrm{a}}$ & $3.39 \pm 0.12^{a}$ & $3.57 \pm 0.12^{a}$ & $3.31 \pm 0.00^{\mathrm{a}}$ & $3.48 \pm 0.00^{a}$ \\
\hline Total fat & $4.51 \pm 0.05^{\mathrm{a}}$ & $4.43 \pm 0.49^{a}$ & $4.44 \pm 0.41^{\mathrm{a}}$ & $4.42 \pm 0.45^{\mathrm{a}}$ & $4.34 \pm 0.61^{\mathrm{a}}$ \\
\hline Total solid & $13.88 \pm 0.06^{\mathrm{a}}$ & $13.73 \pm 0.14^{a}$ & $13.69 \pm 0.00^{a}$ & $13.70 \pm 0.13^{a}$ & $13.08 \pm 1.42^{\mathrm{a}}$ \\
\hline Solid-non-fat & $9.37 \pm 0.10^{\mathrm{a}}$ & $9.30 \pm 0.35^{\mathrm{a}}$ & $9.35 \pm 0.41^{\mathrm{a}}$ & $9.28 \pm 0.58^{a}$ & $8.74 \pm 2.03^{a}$ \\
\hline
\end{tabular}

Note: Mean \pm standard deviation in same row with different superscripts letters are significantly different at $p<0.05$.

In general, the results show that the titratable acidity, specific gravity, total protein, total fat, total solid, and solid-non-fat in both cow and goat milk were not influenced by both HPP and pasteurization. The values changed slightly after HPP treatment but they were statistically insignificant when compared with untreated samples $(p>0.05)$.

\subsection{Effects of HPP on Microbiological Properties}

Table 2 summarizes the microbiological properties of cow and goat milk before and after the treatment. According to the Malaysian Standard for pasteurized milk (MS 410:1995), the total plate count (TPC) should not be more than $10^{5} \mathrm{CFU} / \mathrm{mL}$. In this study, the initial TPC of raw cow and goat milk was $1.5 \times 10^{5} \mathrm{CFU} / \mathrm{mL}$ and $6.9 \times 10^{6} \mathrm{CFU} / \mathrm{mL}$, respectively. Both $\mathrm{HPP}$ and pasteurization produced desirable results of decreased TPC in both milk samples. The pressure regime of $600 \mathrm{MPa} / 5 \mathrm{~min}$ led to the highest TPC reduction in both milk, i.e., $99.98 \%$ for the cow milk and $99.99 \%$ for the goat milk. The lowest TPC reduction was found in the pressure regime of $450 \mathrm{MPa} / 7 \mathrm{~min}(96 \%)$ for the cow milk and for goat milk, it was from the pasteurization process $(99.98 \%)$. This is in line with the findings from Alexandros et al. [14] who found that HPP (600 MPa/3 min) led to a more pronounced decrease of TPC than that of pasteurization. 
Table 2. Microbiological properties of cow and goat milk before and after treatment.

\begin{tabular}{|c|c|c|c|c|c|}
\hline Bacteria Count & Before Treatment & $450 \mathrm{MPa} / 7 \mathrm{~min}$ & $600 \mathrm{MPa} / 5 \mathrm{~min}$ & $600 \mathrm{MPa} / 7 \mathrm{~min}$ & Pasteurized \\
\hline \multicolumn{6}{|c|}{ Cow Milk } \\
\hline Total plate count (CFU/mL) & $1.5 \times 10^{5}$ & $6 \times 10^{3}$ & $2.6 \times 10^{1}$ & $2.5 \times 10^{2}$ & $1.5 \times 10^{2}$ \\
\hline Mesophilic aerobic spore count (CFU/mL) & $7.0 \times 10^{1}$ & $<1$ & $<1$ & $<1$ & $2.0 \times 10^{1}$ \\
\hline Total coliform count $(\mathrm{CFU} / \mathrm{mL})$ & $3.7 \times 10^{1}$ & $<1$ & $<1$ & $<1$ & $<1$ \\
\hline Total yeast and mold count (CFU/mL) & $6.0 \times 10^{1}$ & $<1$ & $<1$ & $<1$ & $<1$ \\
\hline Staphylococcus aureus $(\mathrm{CFU} / \mathrm{mL})$ & $<1$ & $<1$ & $<1$ & $<1$ & $<1$ \\
\hline Total E. coli count (CFU/mL) & $<1$ & $<1$ & $<1$ & $<1$ & $<1$ \\
\hline Thermophilic aerobic spore count (CFU/mL) & $<1$ & $<1$ & $<1$ & $<1$ & $<1$ \\
\hline Listeria monocytogenes per $25 \mathrm{~g}$ & Absent & Absent & Absent & Absent & Absent \\
\hline Salmonella spp. per $25 \mathrm{~g}$ & Absent & Absent & Absent & Absent & Absent \\
\hline \multicolumn{6}{|c|}{ Goat Milk } \\
\hline Total yeast and mold count (CFU/mL) & $8.0 \times 10^{1}$ & $<1$ & $<1$ & $<1$ & $<1$ \\
\hline Bacillus cereus (CFU/mL) & $<1$ & $<1$ & $<1$ & $<1$ & $<1$ \\
\hline Clostridium perfringens $(\mathrm{CFU} / \mathrm{mL})$ & $<1$ & $<1$ & $<1$ & $<1$ & $<1$ \\
\hline Staphylococcus aureus (CFU/mL) & $<1$ & $<1$ & $<1$ & $<1$ & $<1$ \\
\hline Total E. coli count (CFU/mL) & $<1$ & $<1$ & $<1$ & $<1$ & $<1$ \\
\hline Thermophilic aerobic spore count (CFU/mL) & $<1$ & $<1$ & $<1$ & $<1$ & $<1$ \\
\hline Listeria monocytogenes per $25 \mathrm{~g}$ & Absent & Absent & Absent & Absent & Absent \\
\hline Salmonella spp. per $25 \mathrm{~g}$ & Absent & Absent & Absent & Absent & Absent \\
\hline
\end{tabular}

Psychrotrophic bacteria are undesirable for prolonged storage of milk because they are able to grow below $7{ }^{\circ} \mathrm{C}$ even though their optimum temperature ranges from $20{ }^{\circ} \mathrm{C}$ to $30^{\circ} \mathrm{C}$. They also produce heat resistant enzymes, including proteolytic and lipolytic enzymes at low temperatures, which are able to hydrolyze milk fat and protein leading to the formation of off-flavors [30]. According to Malaysians Food Act 1983 and Food Regulations 1985, psychrotrophic bacteria count in milk should not exceed $10^{5} \mathrm{CFU} / \mathrm{mL}$. In this research, the initial psychrotrophic bacteria count in raw cow and goat milk were $9.2 \times 10^{4} \mathrm{CFU} / \mathrm{mL}$ and $8.0 \times 10^{5} \mathrm{CFU} / \mathrm{mL}$, respectively. Both HPP and pasteurization have successfully decreased psychrotrophic bacteria count of both milk samples. The lowest psychrotrophic bacteria count in cow milk was recorded in the pressure regime of $600 \mathrm{MPa} / 7 \mathrm{~min}$ where bacteria was undetectable $(<1 \mathrm{CFU} / \mathrm{mL})$ while the highest count was found in the pressure regime of $450 \mathrm{MPa} / 7 \mathrm{~min}$ $\left(8.3 \times 10^{2} \mathrm{CFU} / \mathrm{mL}\right)$. For goat milk HPP treatment at all pressure regimes have reduced the bacteria count to undetectable level $(<1 \mathrm{CFU} / \mathrm{mL})$. The highest psychrotrophic bacteria count recorded was in the pasteurized sample which is $3.6 \times 10 \mathrm{CFU} / \mathrm{mL}$.

Mesophilic spores are known as the most prevalent spore-former found in bulk milk processing tank. In spore form, these organisms are capable of surviving environmental stresses including low $\mathrm{pH}$, exposure to sanitizers, high pressure and temperature [31]. Mesophilic spores were undetected in all goat milk samples both before and after treatments. For cow milk, the initial mesophilic aerobic spore count was $70 \mathrm{CFU} / \mathrm{mL}$. All pressure regimes in HPP successfully inactivated the spores. However, pasteurization only managed to reduce it to $20 \mathrm{CFU} / \mathrm{mL}$. McGuiggan et al. [32] explained that these aerobic spores have the ability to survive in high temperature as well as pasteurization.

Coliforms are Gram-negative and non-spore forming bacteria that ferment lactose with the production of acid at $35{ }^{\circ} \mathrm{C}$ within $48 \mathrm{~h}$ [33]. According to MS 410:1995, the total coliform should be absent in $0.1 \mathrm{~mL}$ of sample. In this study, the total coliform count for untreated cow milk was $37 \mathrm{CFU} / \mathrm{mL}$, but after treatment, the coliform became undetected in all HPP-treated and pasteurized samples. While all pressure regimes of HPP were able to reduce the total coliform count to undetectable level in goat milk, pasteurization was capable to reduce the counts from $2.1 \times 10^{5} \mathrm{CFU} / \mathrm{mL}$ to $26 \mathrm{CFU} / \mathrm{mL}$ (99.98\% reduction).

Yeast and mold are a large and diverse group which include several hundred species. Although yeast and mold are relatively HPP sensitive [12], mascospores of heat-resistant molds such as 
Byssochlamys, Neosartorya, and Talaromyces are generally considered to be extremely HPP resistant. In this research, the total yeast and mold count of untreated cow and goat milk were $60 \mathrm{CFU} / \mathrm{mL}$ and $80 \mathrm{CFU} / \mathrm{mL}$, respectively. Both HPP and pasteurization were effective in inactivating yeast and mold in cow and goat milk fully. Similar result was reported by Evrendilek [34], where most vegetative yeast and mold were inactivated within $5-10 \mathrm{~min}$ by $300-400 \mathrm{MPa}$ at $25^{\circ} \mathrm{C}$.

Aerobic spore-forming bacteria of the genus Bacillus are commonly present in raw milk. Their spores survive pasteurization and subsequently germinate, outgrow, and multiply [35]. In this study although $B$. cereus was not found in raw cow milk, it was present in HPP-treated and pasteurized milk with the highest count of $20 \mathrm{CFU} / \mathrm{mL}$ in milk subjected to $450 \mathrm{MPa}$ for $7 \mathrm{~min}$. The unexpected presence of $B$. cereus in treated cow milk may be due to several factors. McClements et al. [35] reported that $B$. cereus spores were more resistant to pressure than vegetative cells. The contamination, germination, and outgrowth of Bacillus spores in milk can occur during simple transfer during milking and bottling when hygiene conditions are not fully observed. Post-pasteurization Bacillus cereus adherence to stainless steel contact surfaces in the form of biofilm formation has been reported to occur on milk contact surfaces [36]. Nutrient germinant such as amino acids and unsaturated fatty acids, levels of some indigenous antibacterial factors such as lysozyme, lactoferrin, and lactoperoxidase, somatic cells and metal ions have been suggested as factors influencing the germination of Bacillus species [32,37]. $B$. cereus was not found in both raw and treated goat milk.

C. perfringens, S. aureus, E. coli, L. monocytogenes, Salmonella spp., and thermophilic spores were undetected in both cow and goat milk. The absence of these bacteria and spores is due to good milking hygiene, breeds, climate and geographic location. In India, Chaturvedi and Shukla [38] reported that $51.61 \%$ of raw milk samples were found to be highly contaminated with Clostridium species due to unhygienic milking practice. Mohamed et al. [39] observed no germs of S. aureus and spore of Clostridium spp. in all cow and goat milk samples at Djibouti. However, in the same research, the E. coli count of $2.58 \log$ CFU/mL was significantly higher than standard value of $2 \log C F U / m L$ in their milk samples. Chye et al. [40] reported that only $1.9 \%$ and $1.4 \%$ of cow milk samples in Malaysia were contaminated by L. monocytogenes and Salmonella spp., respectively. Higher incidence of Listeria was obtained from eastern region while Salmonella spp. was found more prevalent in central region of Peninsular Malaysia. Hence, the presence of these bacteria is highly dependent on the location and hygiene.

\subsection{Changes in Physico-Chemical Properties in Milk during Storage}

The $\mathrm{pH}$ for both HPP-treated and pasteurized cow and goat milk decreased significantly $(p<0.05)$ during a 22-day storage period (Figure 1). Similar results were obtained by Siddique et al. [41] who reported $\mathrm{pH}$ declination at the end of 90 days storage of UHT milk. Brodziak et al. [42] mentioned about statistically significant $\mathrm{pH}$ reduction of open drinking cow milk after 7 days of storage. The decreasing trend in pH during milk storage is due to the acidity increase in milk caused by lactic acid and fatty acid [43]. It is obvious that pH of goat milk was always lower than cow milk which may be due to its higher acidity content as shown in Figure 2. This is in agreement with Mahmood and Usman [44] who also found lower $\mathrm{pH}$ in goat milk (6.48) than cow milk (6.59).

Generally, the titratable acidity of both cow and goat milk increased during the 22-day storage (Figure 2). The increment found in all HPP-treated cow milk was statistically insignificant $(p>0.05)$ as compared to significant increment $(p<0.05)$ for pasteurized cow milk with highest acidity of $0.23 \%$ at day 11. For goat milk, all HPP and pasteurized samples titratable acidity was found to have increased significantly, from 0.25 to $0.26 \%$ and $0.30 \%$, respectively at the end of 22-day storage from the range of 0.21 to $0.23 \%$ at day 0 . It is thus obvious that both pasteurized cow and goat milk deteriorated faster than HPP-treated milk. Brodziak et al. [42] also reported increase of titratable acidity in open drinking cow milk after 7-day storage in pasteurized milk, followed by micro-filtered milk and UHT milk. The increase in titratable acidity is mainly due to increasing lactic acid concentration after degradation 
of lactose caused by predominant spoilage lactic acid bacteria (LAB) under low oxygen, temperature, and acidic condition $[41,45]$.
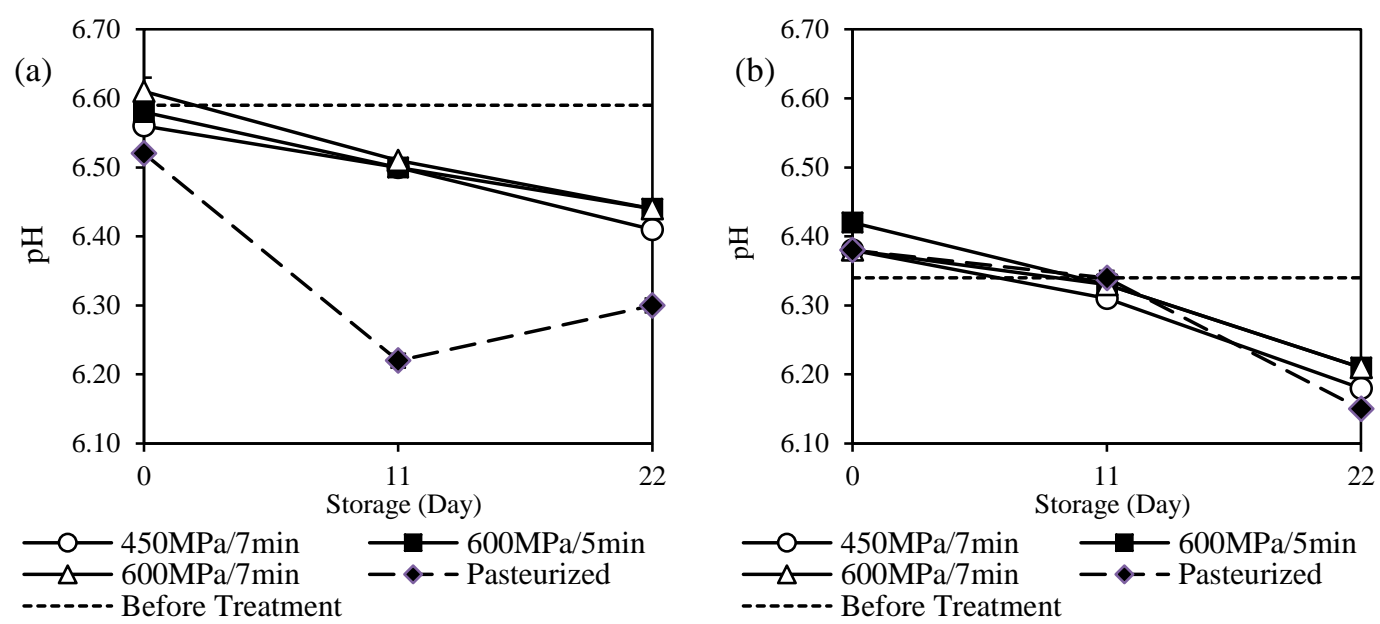

Figure 1. Changes in $\mathrm{pH}$ of (a) cow and (b) goat milk during storage period of 22 days. Solid lines represent HPP-treated milk (450 MPa/7 min, $600 \mathrm{MPa} / 5 \mathrm{~min}, 600 \mathrm{MPa} / 7 \mathrm{~min}$ ), dashed lines represent pasteurized milk, and dotted lines represent fresh milk before treatment.
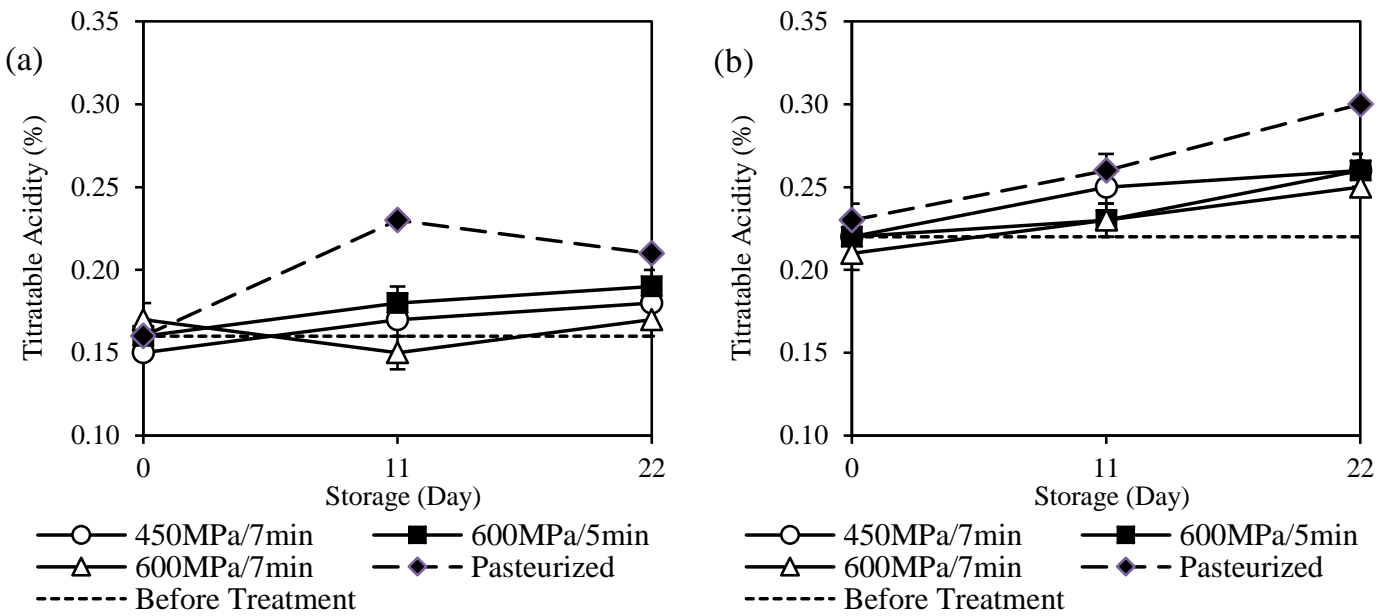

Figure 2. Changes in titratable acidity of (a) cow and (b) goat milk during storage period of 22 days. Solid lines represent HPP-treated milk (450 MPa/7 min, $600 \mathrm{MPa} / 5 \mathrm{~min}, 600 \mathrm{MPa} / 7 \mathrm{~min}$ ), dashed lines represent pasteurized milk, and dotted lines represent fresh milk before treatment.

The specific gravity of both cow and goat milk increased gradually when approaching day 22 of storage (Figure 3). All HPP-treated and pasteurized samples showed a statistically significant increase $(p<0.05)$ in specific gravity except for goat milk in the pressure regime of $450 \mathrm{MPa} / 7 \mathrm{~min}$ which shows significant decrease $(p<0.05)$. The increase in specific gravity agrees with Aldubhany et al. [46]'s work who reported increment in specific gravity in cow milk samples after 6 months of storage at various storage temperatures. The specific gravity of milk could be influenced by the proportion of its constituents such as fat and lactose which degrade during storage [45]. Ahmad et al. [47] proved that milk specific gravity decreased due to mastitis. The authors explained that presence of mastitis contributes to the decrease in lactose and increase in chloride contents as specific gravity is positively correlated with lactose and negatively correlated with chloride. 

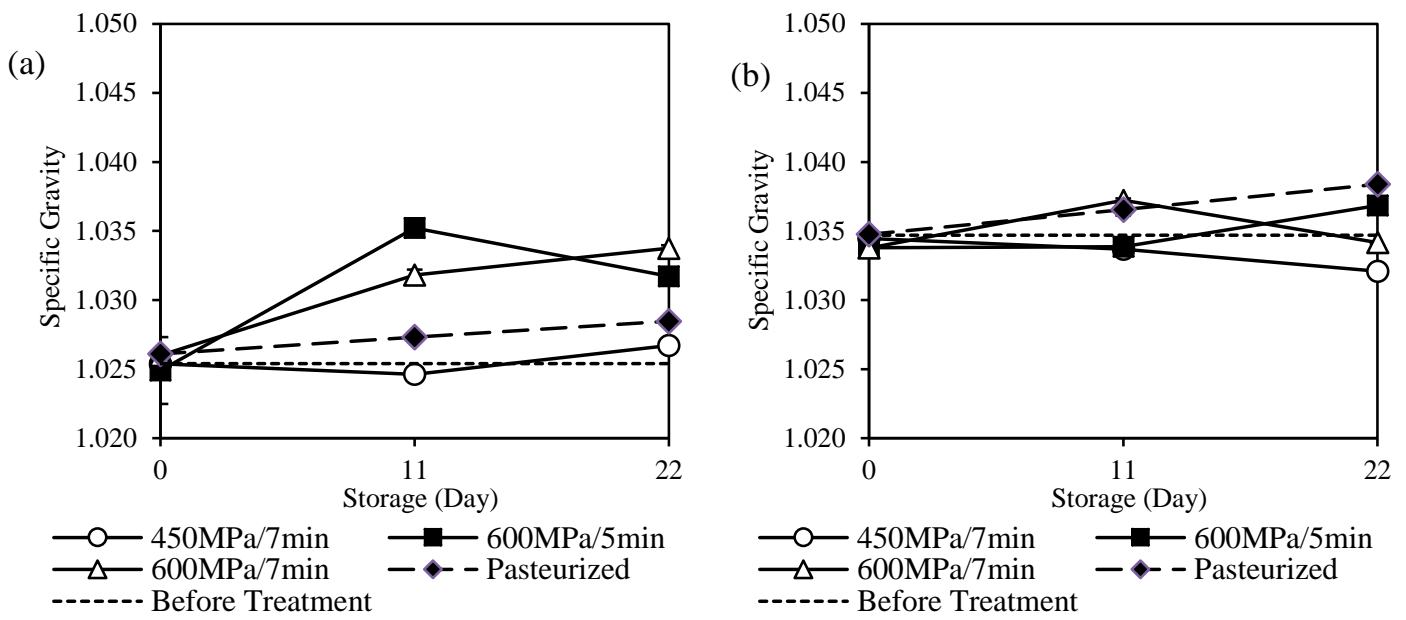

Figure 3. Changes in specific gravity of (a) cow and (b) goat milk during storage period of 22 days. Solid lines represent HPP-treated milk (450 MPa/7 min, $600 \mathrm{MPa} / 5 \mathrm{~min}, 600 \mathrm{MPa} / 7 \mathrm{~min}$ ), dashed lines represent pasteurized milk and dotted lines represent fresh milk before treatment.

Figure 4 shows that the total protein content in both cow and goat milk samples from both HPP and pasteurization treatment did not change significantly $(p>0.05)$ after 22 days. This is supported by Brodziak et al. [42] who found that storage duration of milk had no statistically significant effect on its protein content. Figure 5, however shows that the total fat content of both cow and goat milk samples from pasteurization treatment have reduced significantly $(p<0.05)$ starting from day 11 for cow milk and day 22 for goat milk while no significant difference $(p>0.05)$ was found for HPP samples. The total fat for both pasteurized cow and goat milk have reduced from $3.32 \%$ to $2.94 \%$ while for goat milk from $4.34 \%$ to $3.11 \%$. HPP has been proven to have no damage on the milk fat globule membrane where lipolysis incidence could be prevented, thus the milk fat content could be well preserved [34,48]. Zajác et al. [43] has reported the significant decrease in fat content of raw cow milk after $24 \mathrm{~h}$ of storage at a temperature of $4{ }^{\circ} \mathrm{C}$ to be due to the lipolysis of milk fat initiated by both indigenous milk lipases and also microbial lipases which usually grew in number during storage. Significant increase of free fatty acids as a consequence of lipolysis in UHT cow milk after three weeks of storage was also confirmed by Janstová et al. [49]. These analyses have also shown that goat milk has relatively higher total protein and fat contents than cow milk.
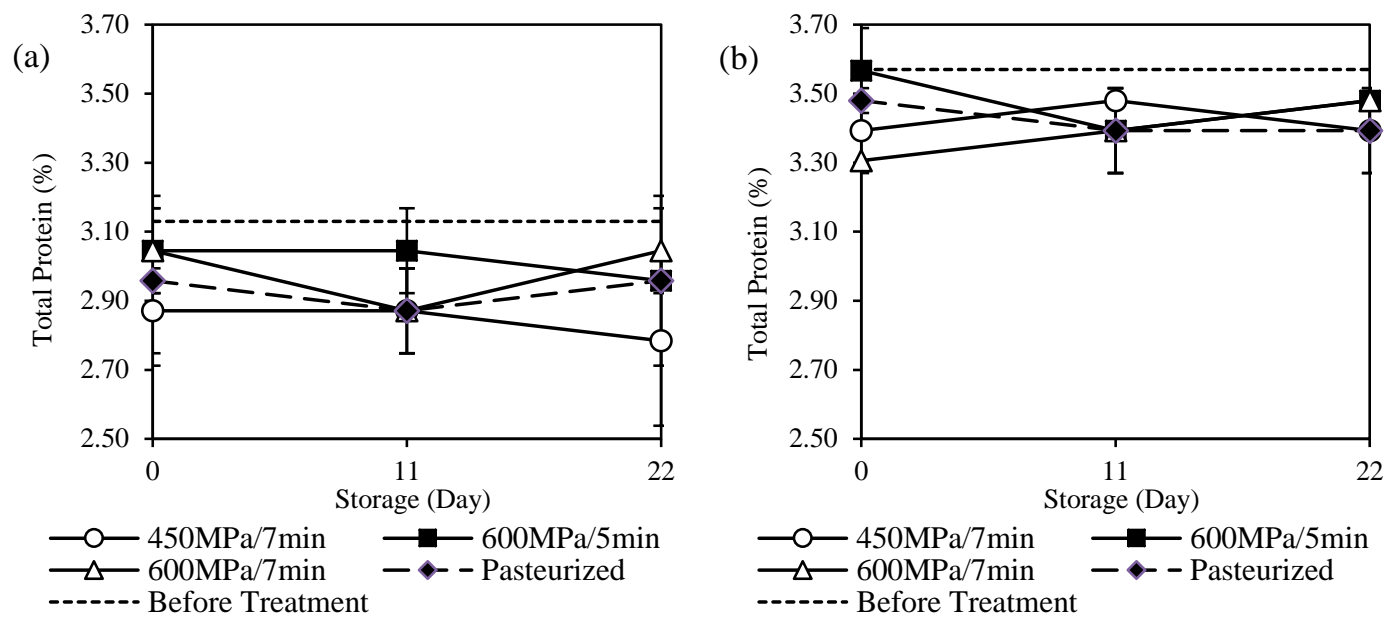

Figure 4. Changes in total protein of (a) cow and (b) goat milk during storage period of 22 days. Solid lines represent HPP-treated milk (450 MPa/7 min, $600 \mathrm{MPa} / 5 \mathrm{~min}, 600 \mathrm{MPa} / 7 \mathrm{~min}$ ), dashed lines represent pasteurized milk and dotted lines represent fresh milk before treatment. 

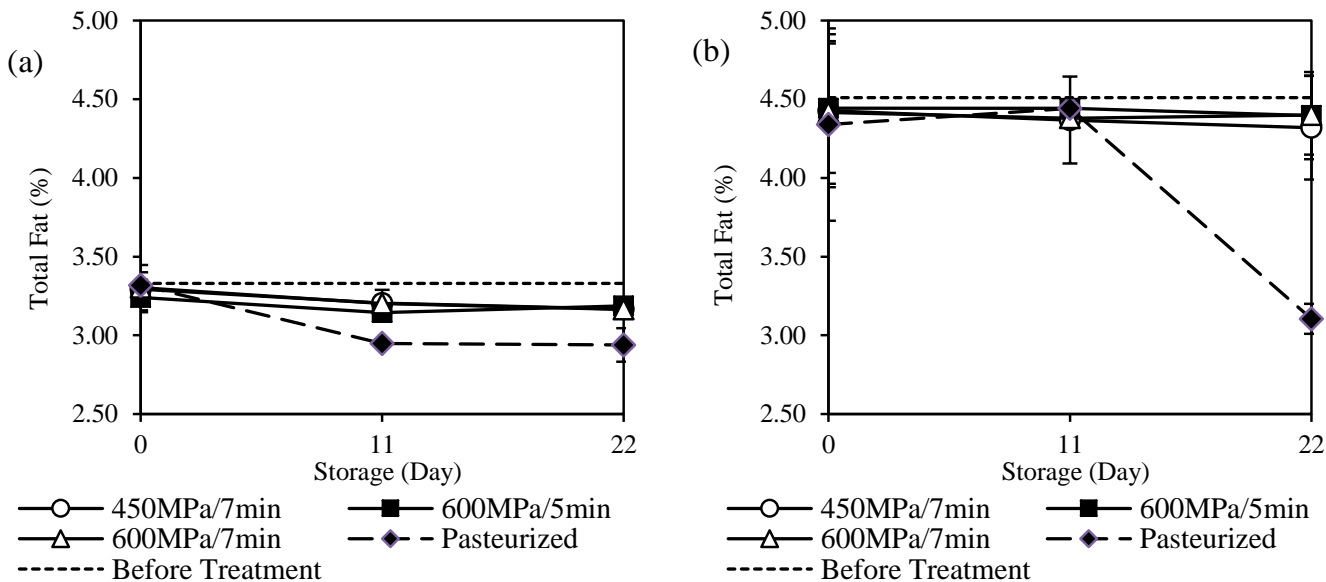

Figure 5. Changes in total fat of (a) cow and (b) goat milk during storage period of 22 days. Solid lines represent HPP-treated milk (450 MPa/7 min, $600 \mathrm{MPa} / 5 \mathrm{~min}, 600 \mathrm{MPa} / 7 \mathrm{~min}$ ), dashed lines represent pasteurized milk, and dotted lines represent fresh milk before treatment.

Figures 6 and 7 show a mimicking trend of total solid and solid non-fat contents of cow and goat milk over the fat content trend, i.e., no significant difference during 22 storage for HPP treated samples and significant decrease $(p<0.05)$ for pasteurized samples. The significant decrease in fat content could affect milk composition in terms of total solid and non-fat contents [43]. Omer and Eltinay [50] have reported similar results where total solid and non-fat content of camel milk reduced significantly after two weeks of storage at $7^{\circ} \mathrm{C}$.
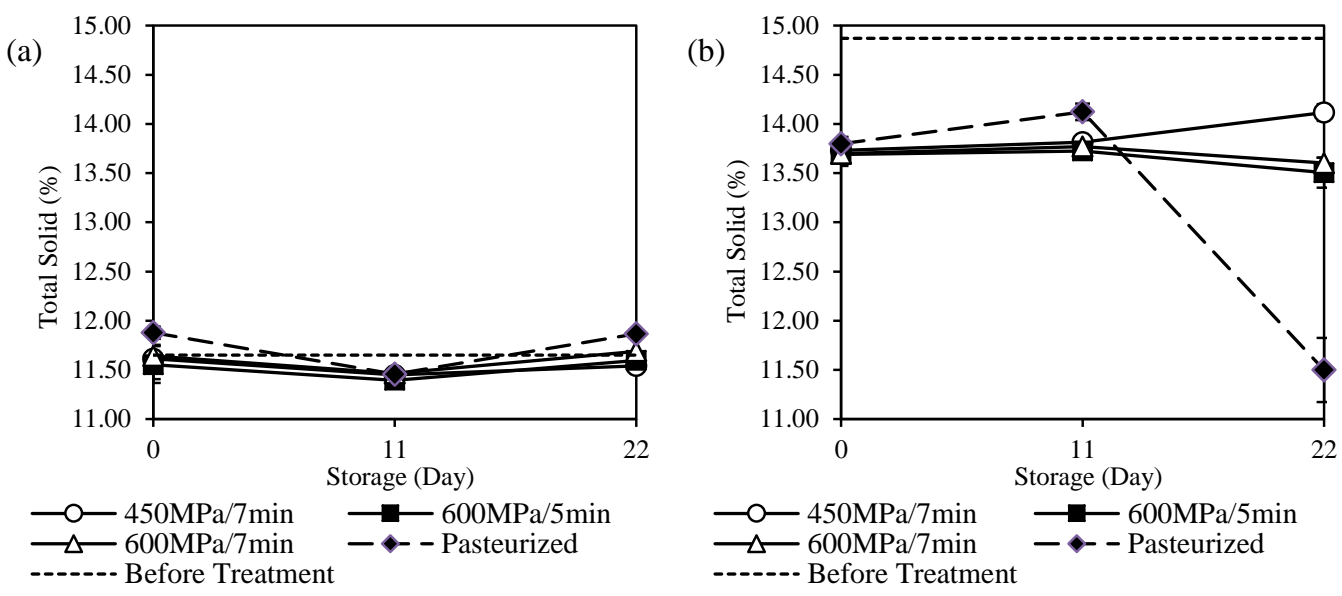

Figure 6. Changes in total solid of (a) cow and (b) goat milk during storage period of 22 days. Solid lines represent HPP-treated milk (450 MPa/7 min, $600 \mathrm{MPa} / 5 \mathrm{~min}, 600 \mathrm{MPa} / 7 \mathrm{~min}$ ), dashed lines represent pasteurized milk, and dotted lines represent fresh milk before treatment.

\subsection{Changes in Microbiological Properties in Milk during Storage}

Table 3 presents the count of two microbiological measurements that turned positive during 22 days of storage. The psychrotrophic bacteria population in both cow and goat milk grew progressively throughout the storage period. At the end of 22 days, the best treatment was HPP at $600 \mathrm{MPa} / 7 \mathrm{~min}$ giving the smallest colony count in cow milk, followed by $600 \mathrm{MPa} / 5$, pasteurization and $450 \mathrm{MPa} / 7 \mathrm{~min}$. All these counts, however, are still far below the limit of $10^{5} \mathrm{CFU} / \mathrm{mL}$ set by the Malaysians Food Act 1983 and Food Regulations 1985. In the case for goat milk, the largest colony count of $9.0 \times 10^{8} \mathrm{CFU} / \mathrm{mL}$ was observed in the pasteurized sample. It exceeded the permissible limit thus considered spoilt at 22 days of storage. The results are in line with Doll et al. [51] who found that $90 \%$ of pasteurized cow milk samples stored at $8{ }^{\circ} \mathrm{C}$ contained $10^{6}$ to $10^{7} \mathrm{CFU} / \mathrm{mL}$ of psychrotrophs at the end of 24 days storage. 
Pressure regime of $600 \mathrm{MPa} / 7$ min presented the best result as the psychrotrophic bacteria in goat milk remained undetectable at day 22. Garcia-Risco et al. [52] reported that the bovine milk sample treated at $400 \mathrm{MPa}$ for $3 \mathrm{~min}$ has a psychrotrophic bacteria count of $10^{6}$ at day 30 of storage at $7^{\circ} \mathrm{C}$.
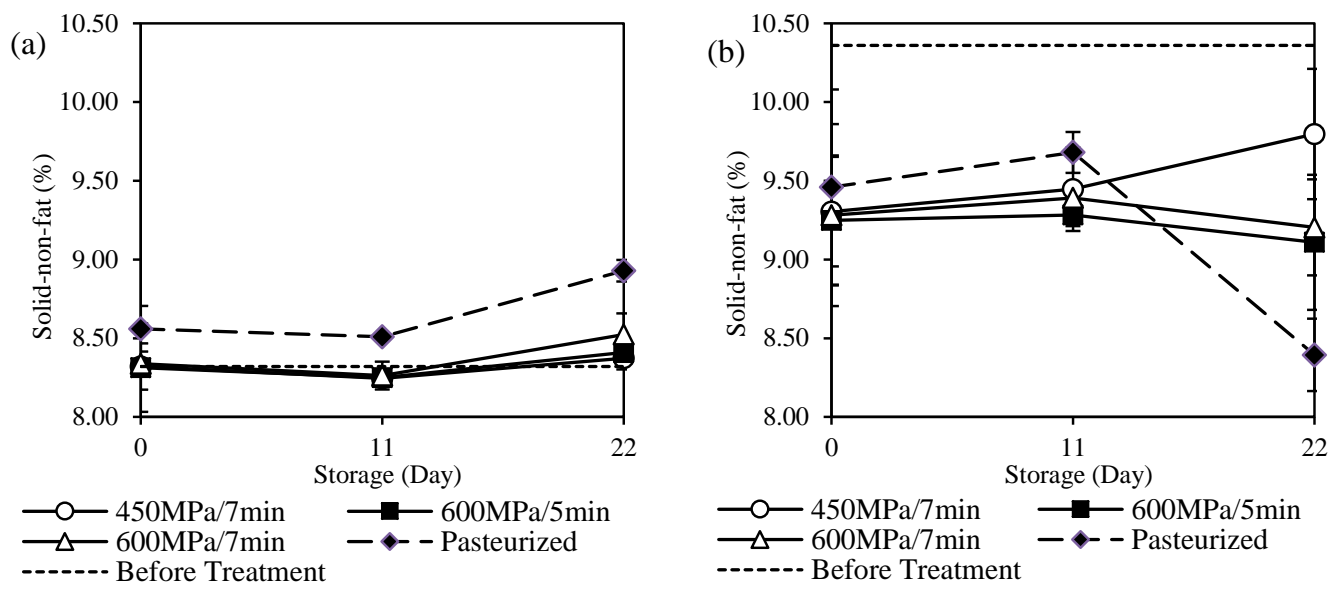

Figure 7. Changes in solid-non-fat of (a) cow and (b) goat milk during storage period of 22 days. Solid lines represent HPP-treated milk (450 MPa/7 min, $600 \mathrm{MPa} / 5 \mathrm{~min}, 600 \mathrm{MPa} / 7 \mathrm{~min}$ ), dashed lines represent pasteurized milk, and dotted lines represent fresh milk before treatment.

Table 3. Psychrotrophic bacteria count and total plate count (CFU/mL) in milk for 22 days of storage.

\begin{tabular}{ccccccc}
\hline \multirow{2}{*}{ Treatment } & \multicolumn{3}{c}{ Cow Milk } & \multicolumn{3}{c}{ Goat Milk } \\
\cline { 2 - 7 } & Day 0 & Day 11 & Day 22 & Day 0 & Day 11 & Day 22 \\
\hline \multicolumn{7}{c}{ Psychrotrophic Bacteria Count } \\
$450 \mathrm{MPa} / 7 \mathrm{~min}$ & $8.3 \times 10^{2}$ & $9.0 \times 10^{3}$ & $3.0 \times 10^{3}$ & $<1$ & $1.0 \times 10^{4}$ & $6.8 \times 10^{1}$ \\
$600 \mathrm{MPa} / 5 \mathrm{~min}$ & 1 & $1.2 \times 10^{4}$ & $4.6 \times 10^{2}$ & $<1$ & $1.8 \times 10^{2}$ & $2.2 \times 10^{1}$ \\
$600 \mathrm{MPa} / 7 \mathrm{~min}$ & $<1$ & $6.4 \times 10^{4}$ & $1.9 \times 10^{2}$ & $<1$ & 3 & $<1$ \\
Pasteurized & $5.4 \times 10^{1}$ & $1.2 \times 10^{4}$ & $2.0 \times 10^{3}$ & $3.6 \times 10$ & $9.0 \times 10^{5}$ & $9.0 \times 10^{8}$ \\
\hline \multicolumn{7}{c}{ Total Plate Count } \\
$450 \mathrm{MPa} / 7$ min & $6.0 \times 10^{3}$ & $2.5 \times 10^{3}$ & $8.0 \times 10^{3}$ & $6.4 \times 10^{2}$ & $2.0 \times 10^{3}$ & $7.6 \times 10^{2}$ \\
$600 \mathrm{MPa} / 5 \mathrm{~min}$ & $2.6 \times 10^{1}$ & $6.0 \times 10^{3}$ & $3.7 \times 10^{2}$ & 6 & $8.8 \times 10^{2}$ & $3.6 \times 10^{4}$ \\
$600 \mathrm{MPa} / 7 \mathrm{~min}$ & $2.5 \times 10^{2}$ & $7.5 \times 10^{4}$ & $2.8 \times 10^{1}$ & $4.0 \times 10^{1}$ & $9.4 \times 10^{1}$ & $8.8 \times 10^{1}$ \\
Pasteurized & $1.5 \times 10^{2}$ & $1.1 \times 10^{4}$ & $3.0 \times 10^{3}$ & $8.0 \times 10^{2}$ & $6.0 \times 10^{5}$ & $3.5 \times 10^{8}$ \\
\hline
\end{tabular}

For TPC, progressive increase was observed during storage period of 22 days. The lowest TPC observed in cow milk at day 22 was in the pressure regime of $600 \mathrm{MPa} / 7 \mathrm{~min}$, followed by $600 \mathrm{MPa} / 5 \mathrm{~min}$, then pasteurization and lastly $450 \mathrm{MPa} / 7 \mathrm{~min}$. Despite the increase, the TPC was still below the limit set by MS 410:1995, which states that the TPC in pasteurized milk should not have TPC above $10^{5} \mathrm{CFU} / \mathrm{mL}$. For goat milk at day 22, the lowest TPC of $8.8 \times 10^{1} \mathrm{CFU} / \mathrm{mL}$ was milk treated at $600 \mathrm{MPa} / 7 \mathrm{~min}$. Pasteurized milk had the highest TPC of $3.5 \times 10^{8} \mathrm{CFU} / \mathrm{mL}$, which exceeded the permissible limit. These results are in agreement with Alexandros et al. [14] who found that TPC for HPP milk was always lower compared to pasteurized where TPC in HPP milk reached $10^{7} \mathrm{CFU} / \mathrm{mL}$ after 28 days compared to pasteurized milk which took only 14 days to reach $>10^{7} \mathrm{CFU} / \mathrm{mL}$. From both the psychrotrophic bacteria population and the TPC microbial count, HPP pressure regime of $600 \mathrm{MPa} / 7 \mathrm{~min}$ is the best for shelf life extension of both milk, renders them the shelf life of more than 22 days.

Other monitored microbes which include C. perfringens, S. aureus, E. coli, L. monocytogenes, Salmonella spp., and thermophilic aerobic spore remained undetected throughout the 22 days of storage. Yeast and mold that has been inactivated by HPP or pasteurization also remained undetected throughout the storage period. Although the Bacillus cereus was found to be present in low number in cow milk at Day 0 after treatment (Table 2), they were not present in all samples on storage Day 11 and 
22. The same situation goes to coliform and mesophilic aerobic spores, which were also present in low number in some pasteurized milk samples at Day 0 after treatment; they were undetected on storage Day 11 and 22. This inconsistent result is most probably due to the randomized sampling and testing of milk from different bottles for each analysis on respective experimental day. The storage results from Table 3 have actually reaffirmed the unexplained presence of coliform and mesophilic aerobic spores after HPP and pasteurization treatments (Table 2) suggesting either it was experimental randomization error or that microbes were inactivated during storage at low storage temperature which may have prevented microbial growth [52] or reduced the microbial count to undetectable levels.

\section{Conclusions}

The results recognized that HPP treatment of 7 min at $450 \mathrm{MPa}$ is sufficient to render both cow and goat milk a shelf life of 22 days at $8{ }^{\circ} \mathrm{C}$, although higher pressure of $600 \mathrm{MPa}$ can give a better safety margin with best treatment results in the order of $600 \mathrm{MPa} / 7 \mathrm{~min}, 600 \mathrm{MPa} / 5 \mathrm{~min}$, and lastly $450 \mathrm{MPa} / 7 \mathrm{~min}$. The HPP treatment has shown better capability of preserving milk than pasteurization where pasteurized goat milk was considered spoilt during storage since both TPC and psychrotrophic bacteria count exceeded the permissible limit. For storage studies, the HPP-treated milk, particularly the cow milk displayed better physico-chemical properties stability compared to the pasteurized. The HPP-treated milk did not show any significant changes in total fat, total solid, and SNF but pasteurized cow and goat milk demonstrated significant changes in $\mathrm{pH}$, titratable acidity, specific gravity, total fat, total solid, and SNF. In terms of microbiological properties, although both HPP and pasteurization were effective in reducing the numbers of TPC, psychrotrophic bacteria, mesophilic spores, coliform, yeast, and mold to far beyond the permissible limit, pasteurization however did not fully inactivate the mesophilic spores and coliform while HPP did. Pressure of $600 \mathrm{MPa}$ for holding time of both 5 and $7 \mathrm{~min}$ have resulted in very low TPC and psychrotrophic bacteria count which is favorable to prolong milk shelf life. The HPP treatment is suggested as a viable alternative treatment for milk if cost is not a consideration, as cost of HPP treatment is much higher.

Author Contributions: S.F.T. designed the experiments, collected and analyzed the data, and wrote the manuscript. N.L.C. conceptualized the study, supervised the research, edited and revised the manuscript. T.P.T. supervised the experiments and S.K.C. provided technical know-how in running the industrial HPP unit. All authors have read and agreed to the published version of the manuscript.

Funding: This research received no external funding.

Conflicts of Interest: The authors declare no conflict of interest.

\section{References}

1. Weaver, C.; Bettoni, R.W.; McMahon, D.; Spence, L. Milk and dairy products as part of the diet. In Milk and Dairy Products in Human Nutrition; Food and Agriculture Organization of the United Nations: Rome, Italy, 2013; pp. 103-183. ISBN 9789251078631.

2. Clark, S.; Garcia, M.B.M. Introduction. A 100-Year Review: Advances in goat milk research. J. Dairy Sci. 2017, 100, 100026-100044. [CrossRef] [PubMed]

3. Ulusoy, B.H. Nutritional and health aspects of goat milk consumption. Akad. Gida 2015, 13, 56-60.

4. Woldemariam, H.W.; Asres, A.M. Microbial and physicochemical qualities of pasteurized milk. J. Food Process. Technol. 2017, 08, 1-5.

5. Barraquio, V.L. Which milk is fresh. Int. J. Dairy Process. Res. 2014, 1, 1-6. [CrossRef]

6. Holsinger, V.H.; Rajkowski, K.T.; Stabel, J.R. Milk pasteurization and safety: A brief history and update. Rev. Sci. Technol. 1997, 16, 441-451. [CrossRef]

7. Ziarno, M.; Molska, I.; Gronczynska, M. Quality and shelf life of milk pasteurized at $84{ }^{\circ} \mathrm{C} / 19-22$ sec and free from post pasteurization contamination. Med. Weter. 2005, 61, 1165-1168.

8. Nagla, B.A.H.; Mohamed, O.M.A.; Abdel, A.M.N. Microbial quality of heat-treated milk during storage. Pak. J. Nutr. 2009, 8, 1845-1848. 
9. Incecco, P.D.; Rosi, V.; Cabassi, G.; Hogenboom, J.A.; Pellegrino, L. Microfiltration and ultra-high-pressure homogenization for extending the shelf-storage stability of UHT milk. Food Res. Int. 2018, 107, 477-485. [CrossRef]

10. Tamime, A.Y. Milk Processing and Quality Management; Wiley-Blackwell: West Sussex, UK, 2014; ISBN 9781444301649.

11. Bogahawaththa, D.; Buckow, R.; Chandrapala, J.; Vasiljevic, T. Comparison between thermal pasteurization and high pressure processing of bovine skim milk in relation to denaturation and immunogenicity of native milk proteins. Innov. Food Sci. Emerg. Technol. 2018, 47, 301-308. [CrossRef]

12. Considine, K.M.; Kelly, A.L.; Fitzgerald, G.F.; Hill, C.; Sleator, R.D. High-pressure processing - effects on microbial food safety and food quality. Fed. Eur. Microbiol. Soc. 2008, 1-9. [CrossRef]

13. Wang, C.; Huang, H.; Hsu, C.; Yang, B.B. Recent Advances in food processing using high hydrostatic pressure recent advances in food processing using high hydrostatic pressure technology. Food Sci. Nutr. 2015, 56, 527-540.

14. Alexandros, C.S.; Elena, S.I.; Mark, L.; Joan, T.; Liam, M.; Nicolae, C.; Anastasios, K.; Brijesh, K.T. Effect of high pressure processing on the safety, shelf life and quality of raw milk. Innov. Food Sci. Emerg. Technol. 2019, 52, 325-333.

15. Chawla, R.; Patil, G.R.; Singh, A.K. High hydrostatic pressure technology in dairy processing: A review. J. Food Sci. Technol. 2011, 48, 260-268. [CrossRef] [PubMed]

16. Elamin, W.M.; Endan, J.B.; Yusof, Y.A.; Shamsudin, R.; Ahmedov, A. High pressure processing technology and equipment evolution: A Review. J. Eng. Sci. Technol. Rev. 2015, 8, 75-83. [CrossRef]

17. Pereda, J.; Ferragut, V.; Quevedo, J.M.; Guamis, B.; Trujillo, A.J. Effects of ultra-high pressure homogenization on microbial and physicochemical shelf life of milk. J. Dairy Sci. 2007, 90, 1081-1093. [CrossRef]

18. Mussa, D.M.; Ramaswamy, H.S. Ultra high pressure pasteurization of milk: Kinetics of microbial destruction and changes in physico-chemical characteristics. Food. Sci. Technol. 1997, 30, 551-557. [CrossRef]

19. Rademacher, B.; Kessler, H.G. High pressure inactivation of microorganisms and enzymes in milk and milk products. In High Pressure Bio-Science and Biotechnology; Elsevier: Amsterdam, The Netherlands, 1997; pp. 291-293.

20. Sharabi, S.; Okun, Z.; Shpigelman, A. Changes in the shelf life stability of ribo fl avin, vitamin C and antioxidant properties of milk after (ultra) high pressure homogenization: Direct and indirect e ff ects. Innov. Food Sci. Emerg. Technol. 2018, 47, 161-169. [CrossRef]

21. Amador-espejo, G.G.; Gallardo-chacon, J.J.; Nykänen, H.; Juan, B.; Trujillo, A.J. Effect of ultra high-pressure homogenization on hydro- and liposoluble milk vitamins. FRIN 2015, 77, 49-54. [CrossRef]

22. Yang, B.; Shi, Y.; Xia, X.; Xi, M.; Wang, X.; Ji, B.; Meng, J. Inactivation of foodborne pathogens in raw milk using high hydrostatic pressure. Food Control 2012, 28, 273-278. [CrossRef]

23. Pyne, G.T. The determination of milk-proteins by formaldehyde titration. Biochem. J. 1932, $26,1006$. [CrossRef]

24. Gomaa, M.S.; Abdel-Aziz, M.E.; Hafez, E.H.; Salama, S.I. New method for determination of protein content of goat's milk and compared with different methods. J. Food Dairy Sci. Mansoura Univ. 2014, 5, 95-101. [CrossRef]

25. Ma, Y.; Barbano, D.M. Milk pH as a Function of $\mathrm{CO}_{2}$ concentration, temperature, and pressure in a heat exchanger. J. Dairy Sci. 2003, 86, 3822-3830. [CrossRef]

26. José, M.P.; Adriano, G.; Bruna, W.M.; Daniel, N.L.; Claucia, F.V. Effects of pasteurization and ultra-high temperature processes on proximate composition and fatty acid profile in bovine milk. Am. J. Food Technol. 2015, 10, 265-272.

27. Chopde, S.S.; Deshmukh, M.A.; Kalyankar, S.D.; Changade, S.P. Applications of high pressure technology for milk processing. Res. J. Anim. Husb. Dairy Sci. 2014, 5, 143-147. [CrossRef]

28. Liepa, M.; Zagorska, J.; Galoburda, R. Effect of high pressure processing on milk coagulation properties. Res. Rural Dev. 2017, 1, 223-229.

29. Zobrist, M.R.; Huppertz, T.; Uniacke, T.; Fox, P.F.; Kelly, A.L. High-pressure-induced changes in the rennet coagulation properties of bovine milk. Int. Dairy J. 2005, 15, 655-662. [CrossRef]

30. Samaržija, D.; Zamberlin, Š.; Pogačić, T. Psychrotrophic bacteria and their negative effects on milk and dairy products quality psychrotrophic bacteria and milk and dairy products quality. Mijekarstvo 2012, 62, 75-95. 
31. Kent, D.J.; Chauhan, K.; Boor, K.J.; Wiedmann, M.; Martin, N.H. Spore test parameters matter: Mesophilic and thermophilic spore counts detected in raw milk and dairy powders differ significantly by test method. J. Dairy Sci. 2016, 99, 5180-5191. [CrossRef]

32. McGuiggan, J.T.M.; McCleery, D.R.; Hannan, A.; Gilmour, A. Aerobic spore-forming bacteria in bulk raw milk: Factors influencing the numbers of psychrotrophic, mesophilic and thermophilic Bacillus spores. Int. J. Dairy Technol. 2002, 55, 100-107. [CrossRef]

33. Wanjala, W.N.; Nduko, J.M.; Mwende, M.C. Coliforms Contamination and hygienic status of milk chain in emerging economies. J. Food Qual. Hazards Conrol 2018, 5, 3-10. [CrossRef]

34. Evrendilek, G. Non-thermal processing of milk and milk products for microbial safety. In Dairy Microbiology and Biochemistry: Recent Developments; CRC Press: Boca Raton, FL, USA, 2017; pp. 322-355.

35. McClements, J.M.; Patterson, M.F.; Linton, M. The effect of growth stage and growth temperature on high hydrostatic pressure inactivation of some psychrotrophic bacteria in milk. J. Food Prot. 2001, 64, 514-522. [CrossRef] [PubMed]

36. Chmielewski, R.A.N.; Frank, J.F. Biofilm formation and control in food processing facilities. Compr. Rev. Food Sci. F 2006, 2, 22-32. [CrossRef]

37. Christiansson, A.; Bertilsson, J.; Svensson, B. Bacillus cereus spores in raw milk: Factors affecting the contamination of milk during the grazing period. J. Dairy Sci. 1999, 82, 305-314. [CrossRef]

38. Chaturvedi, A.; Shukla, S. Occurance of Clostridium species in different dairy products and its associated health risk. Int. J. Recent Sci. Res. 2015, 6, 2827-2829.

39. Mohamed, A.F.; Somda, M.K.; Fourreh, A.E.; Okieh, A.A.; Said, C.N.; Merito, A.; Yagi, S. Evaluation of microbiological quality of raw milk from farmers and dairy producers in six districts of Djibouti. J. Food Microbiol. Saf. Hyg. 2017, 02.

40. Chye, F.Y.; Abdullah, A.; Ayob, M.K. Bacteriological quality and safety of raw milk in Malaysia. Food Microbiol. 2004, 21, 535-541. [CrossRef]

41. Siddique, F.; Riffat, S.; Arshad, M.; Farooq, U.; Iftikhar, K.; Kharal, S. Effect of storage temperature on the physiochemical properties of UHT milk. Int. J. Food Allied Sci. 2016, 2, 52. [CrossRef]

42. Brodziak, A.; Krol, J.; Litwinczuk, Z.; Zaborska, A.; Czernecki, T. Effect of storage time under home refrigeration conditions on the quality of opened drinking milk. Mljekarstvo 2017, 67, 283-296. [CrossRef]

43. Zajác, P.; Čapla, J.; Vietoris, V.; Zubrická, S.; Čurlej, J. Effects of storage on the major constituents of raw milk. Potravin. Sci. J. Food Ind. 2015, 9, 375-381. [CrossRef]

44. Mahmood, A.; Usman, S. A comparative study on the physicochemical parameters of milk samples collected from buffalo, cow, goat and sheep of Gujrat, Pakistan. Pak. J. Nutr. 2010, 9, 1192-1197. [CrossRef]

45. Rawat, S. Food Spoilage: Microorganisms and their prevention. Pelagia Res. Libr. Asian J. Plant Sci. Res. 2015, 5, 47-56.

46. Aldubhany, T.A.W.; Gouda, E.; Khattab, A.; Dabour, N. Effects of storage on some physico-chemical characteristics of uht milk stored at different temperature. Alexandria Sci. Exch. J. 2014, 35, 107-114.

47. Ahmad, T.; Bilal, M.Q.; Ullah, S.; Muhammad, G. Effect of severity of mastitis on $\mathrm{pH}$ and specific gravity of buffalo milk. Pak. J. Agri. Sci. 2005, 42, 64-67.

48. Huppertz, T.; Kelly, A.L.; Fox, P.F. Effects of high pressure on constituents and properties of milk. Int. Dairy J. 2002, 12, 561-572. [CrossRef]

49. Janstová, B.; Lukasová, J.; Dracková, M.; Vorlová, L. Influence of Bacillus spp. enzymes on ultra high temperature-treated milk proteins. Acta Vet. Brno 2004, 73, 393-400.

50. Omer, R.H.; Eltinay, A.H. Changes in chemical composition of camel raw milk during storage. Pak. J. Nutr. 2009, 8, 607-610.

51. Doll, E.V.; Scherer, S.; Wenning, M. Spoilage of Microfiltered and pasteurized extended shelf life milk is mainly induced by psychrotolerant spore-forming bacteria that often originate from recontamination. Front. Microbiol. 2017, 8, 1-13. [CrossRef] [PubMed]

52. Garcia-Risco, M.R.; Cortes, E.; Carrascosa, A.V.; Lopez-Fandino, R. Microbiological and chemical changes in high-pressure- treated milk during refrigerated storage. J. Food Prot. 1998, 61, 735-737. [CrossRef] [PubMed]

(C) 2020 by the authors. Licensee MDPI, Basel, Switzerland. This article is an open access article distributed under the terms and conditions of the Creative Commons Attribution (CC BY) license (http://creativecommons.org/licenses/by/4.0/). 